\title{
多発性腰椎後縦靱帯骨化の治療経験
}

\author{
熊本中央病院 \\ 大串幹・前川清 継 \\ 森田直

\section{Patients with Multiple Ossification of the Posterior Longitudinal Ligament of the Lumber Spine} \\ by \\ Miki Ohgushi, Kiyotsugu Maekawa and Sunao Morita \\ Department of Orthopaedic Surgery, \\ Kumamoto Chuo Hospital.
}

\begin{abstract}
The posterior longitudinal ligament, together with the yellow ligament, ossifies and thickens due to ageing and physical constitution, and readily compresses the spinal cord and nerve root, producing neurological symptoms. Since the 1960s, a number of patients with posterior longitudinal ligament ossification have been reported, and the treatment has been nearly established.

Most of these patients had ossification in the cervical spine, but some had lesions in the thoracic or lumber spine. We report 2 patients with posterior longitudinal ligament ossification of the lumber spine that is relatively infrequently observed and discuss the clinical problems.

Patient 1: A 57-year-old female. Enlargement of the spinal canal performed for ossification of the posterior longitudinal ligament of the cervical spine did not improve the symptoms in the right lower limb. X-ray examination revealed multiple ossification of the posterior longitudinal ligament of the lumber spine. Patient 2: A 52-year-old female. On the next day of a mortorbike accident, lumbago and symptoms in the lower limbs appeared. X-ray examination revealed ossification of the posterior longitudinal ligament of the thoracic and lumber spine.
\end{abstract}

Surgery on the lumbar spine was performed in both patients.

\section{は じめに}

後綐靯帯は加令や体質による骨化，肥厚を生じ，黄 色䩗帯とあわせ，容易に脊髄および神経根を圧迫し， 神経症状を呈する. 1960 年代より多くの症例が報告さ れ，治療法も確立されつつある．また後縦靯帯骨化は 頸椎だけでなく, 胸・腰椎部にも生じることが知られ ており ${ }^{117)}$, 前縦䩲帯, 黄色靱帯の骨化とあわせて, 春 柱勒带骨化症の概念も出されている.今回われわれは, 比較的頻度の少ない多椎間におよぶ腰椎後縦勒帯骨化 の 2 症例を経験したので,若干の考察を加え報告する.

$$
\text { 症例 }
$$

症例 $1: 57$ 才性
主訴：後頸部，腰痛．右上肢, 両下肢痛

現病歷：昭和 61 年初め, 頸部から右上肢に放散する 痛みが出現, 徐々に增強。近医受診し, 頸椎後綐䩡帯 骨化が認められ，保存的治療うけるも効果なし．昭和 61 年 6 月当科紹介され, 7 月入院となった。

既往歷：47 才時尿路結石

家族歴：特記すべきことなし

初診時一般所見：身長 $156 \mathrm{~cm}$, 体重 $55 \mathrm{~kg}$

全身状態良好. 血液生化学検査に異常なし.

自覚症状 : 後頸部, 腰部鈍痛 $(+)$, 右上肢, 両下肢

痛 $(+)$ (頸を動かすと増悪する)

初診時神経学的所見 : 知覚低下 $(+)$ (右上肢 $C_{5}$ 以 下, 左上肢 $\mathrm{C}_{6}$ 以下, 体幹, 下肢 $\mathrm{Th}_{8}$ 以下). 四肢腱反 射穴進 $(+)$. 筋力低下 $(-)$. 機能障害程度は上肢 $C \sim D$ 
下肢 C

初診時 $\mathrm{X}$ 線所見 : 単純 $\mathrm{X}$ 線像で $\mathrm{C}_{2} \sim \mathrm{C}_{6}$ の後縦靯帯 骨化が存在し，ミエログラフィーでは $\mathrm{C}_{3} \sim \mathrm{C}_{6}$ で狭窄が 認められた（図 $1-a, b, c)$ 。

入院後経過：昭和 61 年 7 月 20 日, $\mathrm{C}_{3} \sim \mathrm{C}_{6}$ の頸椎管 拡大術を施行した (図 $1-\mathrm{d}, \mathrm{e})$. 術後徐々に知覚障害, 右上肢痛は軽快した。しかし 9 日初め歩行訓練を開始 した頃より，腰から右下肢にかけての疼痛が増強。腰 椎 $X$ 線検查にて $\mathrm{L}_{2 / 3}, \mathrm{~L}_{3 / 4}, \mathrm{~L}_{4 / 5}, \mathrm{~L}_{5} / \mathrm{S}_{1}$ に多発性の後繸 勒帯骨化を認めた（図 2)。神経学的には左 $\mathrm{L}_{4.5}$ 領域の 知覚低下と右側に L Lasëgue 徵候を認めた。神経根ブロ ックにて, 両側の $\mathrm{L}_{3 / 4}, \mathrm{~L}_{4 / 5}, \mathrm{~L}_{5} / \mathrm{S}_{1}$ に pain respons が あり, 保存的治療では効果がないため, 昭和 62 年 2 月 18 日, $\mathrm{L}_{3 / 4}, \mathrm{~L}_{4 / 5}, \mathrm{~L}_{5} / \mathrm{S}_{1}$ の両側 Love 法と右側の foraminotomy を行った。術後は左 $\mathrm{L}_{5}$ 知覚領域に極軽度 の知覚低下を残しているが, 疼痛軽快し, 現在外来経
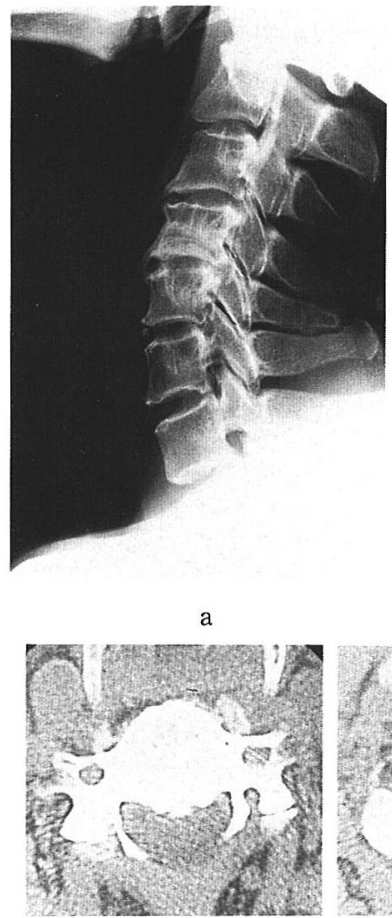

d

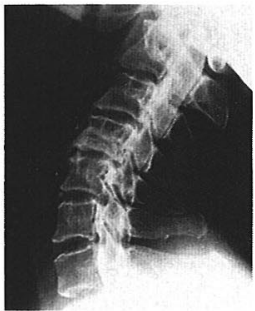

b

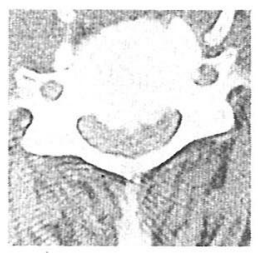

c

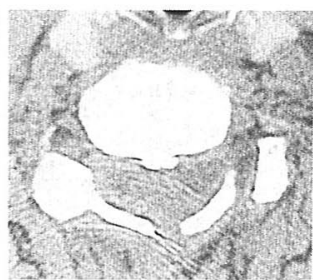

e
图 1 症例 1

a 、頸椎後縦勒带骨化を示す

b. ミエログラフィーにて $\mathrm{C}_{3}$ から $\mathrm{C}_{7}$ にかけて 狭窟を認める

c。術前単純 CT 像

d. e. 術後単純 CT 像

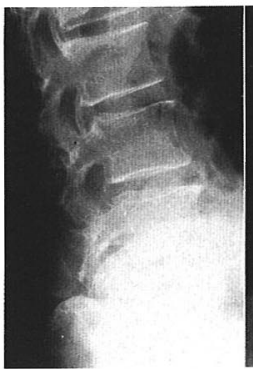

a

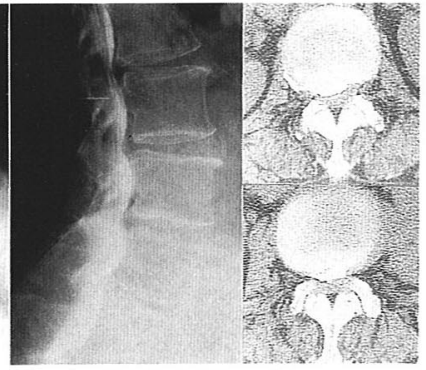

$\mathrm{b}$
図 2 症例 1

a. b. 腰椎単純X線像にて $\mathrm{L}_{2 / 3}$ より $\mathrm{L}_{5} / \mathrm{S}_{1} に$ かけて後縦鞀带骨化を認め, ミエログラフィー にて同部に狭窄を認めた。

c. 腰椎単純 $\mathrm{CT}$ 像

過観察中である。

症例 $2: 52$ 才 女性

主訴：左殿部，左下肢の疼痛としびれ感

現病歴：昭和 61 年 4 月 8 日,バイク走行中に交通事 故に遭遇。翌日より腰痛と左下肢痛, しびれ感出現し, 徐々に増悪するため 5 月 15 日当科を紹介され受診し た。

既往歴： 50 才時子宮筋腫で手術. 52 才時より高血 圧，心肥大指摘され内服治療中.

家族歴：特記すべきことなし。

初診時一般所見：身長 $148 \mathrm{~cm}$, 体重 $74 \mathrm{~kg}$. 血圧 $150 / 90 \mathrm{mmHg}$, 血液生化学検查では血清トランスアミ ナーゼの軽度上昇がみられ，糖代謝検査では糖尿病が 示唆された。

初診時神経学的所見 : 腰椎運動制限 $(+)$, 運動痛 $(+)$ ，下位胸椎加ら腰椎の棘突起，傍沗柱筋に圧痛 $(+)$. 知覚低下 $(+)$ ( $\mathrm{Th}_{10}$ 以下). 両下肢腱反射六進 $(+)$. 右 $40^{\circ}$, 左 $30^{\circ}$ で Lasëgue 徵候を認めた。筋力 低下 $(-)$. 膀胱直腸障害 $(-)$.

初診時X線所見：単純 $\mathrm{X}$ 線像で $\mathrm{L}_{2 / 3}, \mathrm{~L}_{3 / 4}, \mathrm{~L}_{4 / 5}, \mathrm{~L}_{5} /$ $\mathrm{S}_{1}$ に多発性の後綐鞋帯骨化を認めた。頸椎にはなかっ た。またミエログラフィーでも腰椎後縦靯带骨化部に 狭窄がみられた（図 3 )。

入院後経過：腰腎部の疼痛著明なため, 昭和 61 年 8 月 22 日， $\mathrm{L}_{4}$ 下縁から $\mathrm{S}_{1}$ 上縁まで laminectomy, foraminotomy として postero-lateral fusion を行なった。 術中, 後縦勒帯骨化を確認し, 脊䯣の前方からの圧迫 を認めたが，神経根の圧迫は著明ではなかった。術後 


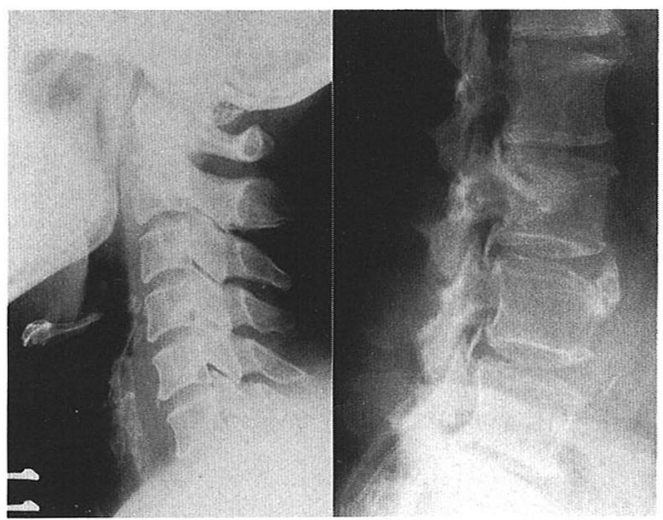

a

b

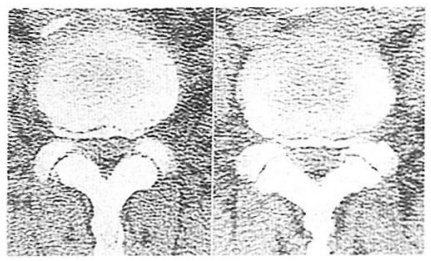

c

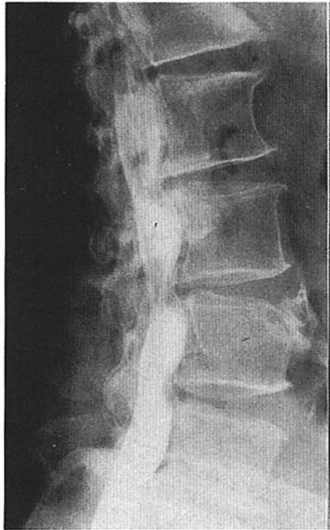

d

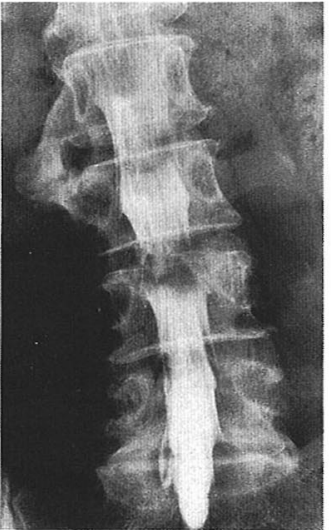

図 3 症例 2

a . 頸椎単純X線像では後綐勒带骨化を認めな w.

b. 腰椎単純 $\mathrm{X}$ 線像にて $\mathrm{L}_{2 / 3}$ より $\mathrm{L}_{5} / \mathrm{S}_{1}$ に後縦 靶帯骨化を認める.

c. 腰椎単純 CT 像

d. e .ミエログラフィーでも骨化部に一致し た狭窄を認める。

経過良好で, $\mathrm{Th}_{10}$ 以下の知覚低下はみられたが, $\mathrm{L}_{4}$ 以 下は術前に比べ改善し, 10 月にはコルセット装着にて 歩行可能となった。しかし活動性が高くなるに従い,

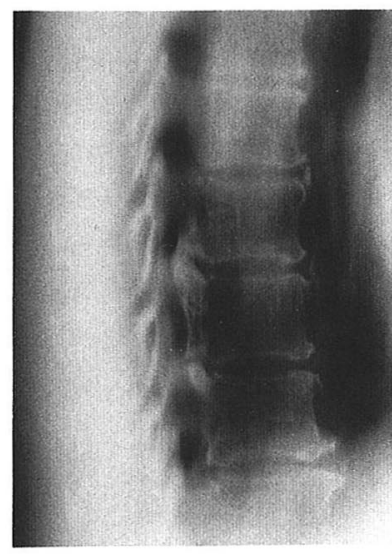

a

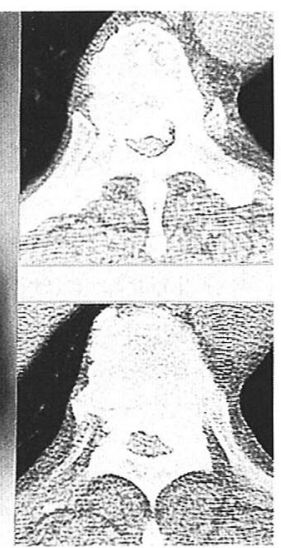

b
図 4 症例 2

a. Th $9 ， 10,11$ に後綐䩲帯骨化を認める

c. CT 像

背部痛, 左下肢痛が増強し, 神経根ブロック施行する も効果ないため, 胸椎のX線検査を行った。断層にて $\mathrm{Th}_{9}$ から $\mathrm{Th}_{11}$ にかけ後綐䩲帯骨化が認められた（図 4 ). しかし症状の責任病巣が確定できず，その後保存 的療法で経過をみている。

$$
\text { 考察 }
$$

胸腰椎部後縦靯带骨化は黄色靱帯の骨化とあわせて, 脊柱管狭窄症の原因病変の一つ，さらに前縦靶帯骨化 を加えて, 変形性脊椎症の病態の一つと考えられる。 われわれの症例では後縦靱帯骨化が多発性に認められ たこと，また結石や糖尿病の既往などにより，骨化傾 向に関連する全身性の要因が示唆される。また骨化が 主に後縦靶帯に生じ，しかも多発することの比較的少 ない腰椎に 4 椎間に存在したことは，何らかの局所的 要因の関与も考えられる。

頸椎だけでなく，胸腰椎部に骨化の存在するものは 女性に多い ${ }^{7)}$ とされ，骨化形態に関しては, 頸椎部は連 続型が多く,胸腰椎部は断続型が多いとされている35)6). われわれの症例もそれらの傾向を有していたが，この ように多椎間におよぶ胸腰椎部後緃䩲帯骨化の頻度は 少ないとされている。

われわれの症例のように病変が頸椎と腰椎, 胸椎と 腰椎に存在する場合は, その責任病巣（責任高位）の 決定は困難である。われわれは診断にあたっては，疼 痛部位, 神経症状, X線所見に加え, 臨床経過から推 
定し，それにもとずき治療した。診断確定のためには， さらに電気生理学的検査が必要と思われる，治療に関 しても，骨化が多椎間におよぶ場合には，その手術方 法の選択も難しく ${ }^{2) 4)}$, 報告者によっては, 結果は必ず しも良くないことが示されている，われわれは腰椎部 に対しては徐圧を目的とした手術を行い，胸椎部に対 しては 3 椎間におよぶことより経過をみているが，徐 圧により生じる不安定性, 脊椎変形を防ぐ手術方法が 必要であると考えている。

$$
\text { ま と め }
$$

比較的頻度の少ない多発性腰椎後縦靱帯骨化の 2 症 例を経験したので, 若干の考察を加えて報告した。

\section{参 考 文 献}

1) Bozman, R.E. and Downey, E.F.: DISH and OPLL in the thoracic spine. Computerized Radiol. 9 $-2: 243-246,1985$.

2) 後藤澄雄, 井上駿一・他：腰部後縦勒帯骨化の病態と 治療. 整形外科 Mook, $50 ： 317-329 ， 1987$.

3）野田基博, 河野 清-他：腰椎後縌靯带骨化の臨床的 検討. 整・災外， $36 ： 480-482 ， 1987$.

4）砂金光藏，河合伸也・他：胸椎部脊柱靯帯骨化症の観 血的治療. 整形外科 Mook, $50: 303-316,1987$.
5）土屋恒篤, 今井清勝・他：胸腰椎後縦靯帯骨化. 整形 外科, $26: 667-672,1975$.

6）津山直一, 黒川高秀 : 胸腰椎部の後縦勒带骨化症につ いて. 臨整外, $12: 337-339,1977$.

7) Tsuyama N.: Ossification of the posterior longitudinal ligament of spine J. Clin. Orthop. 184: 71-84, 1984.

\section{質 問山口大学 斉鹿稔}

第 2 例は, 神経症状から考えて胸椎 OPLLに外傷が 加わって脊損を呈したものと考えますが，いかがでし ようか.

解 答熊本中央病院 大串 幹

(1) 症例 2 は御指摘の通り交通事故にひきつづき症 状発現しており, 症状も脊髄損傷の様相を呈していま した. 手術は最初腰椎に対し施行しましたが, これは 下肢筋力低下，膀胱直腸障害を認めず，患者の訴えが 腰部を中心とした腰椎にあったためです。

(2) 術前に神経根ブロックは施行していません，X 線で術前に OYL か OPLL かはっきりしませんでした が胸椎部に骨化像を認めていました，胸椎部に責任病 巣が存在する可能性は示唆されましたが, (1)の理由で 腰椎に対する手術を優先させました。 